\title{
Geochemical evaluation of shale formations in the northern Song Hong basin, Vietnam
}

\author{
V.T. H. Quan ${ }^{1}$ ·P. H. Giao' ${ }^{1}$
}

Received: 20 August 2018 / Accepted: 19 April 2019 / Published online: 2 May 2019

(c) The Author(s) 2019

\begin{abstract}
Petroleum exploration and production of conventional reservoirs have been strongly developed over the years in Vietnam since 1987. However, with the decrease in petroleum production in recent years, a certain attention has started to be given to the unconventional reservoirs. This study presents the results of a comprehensive geochemical evaluation of three main shale formations in the northern Song Hong basin (also known as the Red River basin) of Vietnam. Over 200 cutting samples of Lower Miocene, Oligocene and Triassic shales from two onshore and two offshore wells were collected and tested for total organic carbon (TOC), hydrocarbon generation potential (S2), hydrogen index (HI), production index (PI), $T_{\max }$ and vitrinite reflectance $\left(R_{\mathrm{o}}\right)$. Lower Miocene shales are characterized by HI of 94 to $591 \mathrm{mgHC} / \mathrm{gTOC}$, TOC of 0.14 to $1.65 \mathrm{wt} \%$ and S2 of 0.34 to $4.62 \mathrm{mg} \mathrm{HC} / \mathrm{g}$ rock, indicating a poor-to-fair source rock of mixed gas-prone kerogen types II and III. Their $T_{\max }$ of 425 to $437{ }^{\circ} \mathrm{C}$ and $R_{\mathrm{o}}$ of 0.35 to $0.66 \%$ suggested an immaturity to early-maturity HC generation. Oligocene shales have HI of 164 to $602 \mathrm{mgHC} / \mathrm{gTOC}$, TOC of 0.52 to $3.18 \mathrm{wt} \%$ and S2 of 0.63 to $5.61 \mathrm{mg} \mathrm{HC/g}$ rock, indicating a fair-to-good potential source rock with a gas- and oil-prone kerogen of mixed types II and III. Their $T_{\max }$ values of 427 to $476{ }^{\circ} \mathrm{C}$ and $R_{\mathrm{o}}$ of 0.43 to $1.73 \%$ suggested an optimum thermal maturity. Triassic shales are characterized by $\mathrm{HI}<50 \mathrm{mgHC} / \mathrm{gTOC}$, TOC from 1.04 to $14.10 \mathrm{wt} \%$ and S2 from 0.03 to $1.11 \mathrm{mg} \mathrm{HC/g}$ rock, showing little remaining source or no potential for hydrocarbon generation in the late to post-mature stages with $R_{\mathrm{o}}$ of 1.79 to $2.10 \%$. The newly obtained geochemical data and analysis results of this study are expected to improve the knowledge on the main source rocks in the northern Song Hong basin, in particular in the onshore part and to provide with the useful background information for further assessment of shale gas potential in Vietnam.
\end{abstract}

Keywords Shale gas $\cdot$ The northern Song Hong basin $\cdot$ TOC-Rock-Eval pyrolysis $\cdot$ Vitrinite reflectance $\cdot$ Kerogen type

\section{Introduction}

Shale reservoirs have become more and more important and active exploration plays for many countries in the world, typically in the USA (Dejam et al. 2018; Zhang et al. 2018). A series of reports from EIA provided the initial assessments of world shale oil and shale gas resources. The first edition was released in 2011, and updates are released on an ongoing basis. EIA (2013) reported a total of 46 countries, not including Vietnam, were technically assessed for recoverable shale gas unproved resources. As a matter of fact, the studies

\section{P. H. Giao}

hgiao@ait.asia

1 Geosystem Exploration and Petroleum Geoengineering (GEPG) Program, School of Engineering and Technology, Asian Institute of Technology, Bangkok, Thailand on the unconventional HC resources in Vietnam, in particular the shale gas potential, are still in the infancy stage. Sheikh and Giao (2017) applied an integrated approach to calculate hydrocarbon potentially retained in a source rock to evaluate shale gas potential of the Southern Indus Basin, Pakistan. In this study, the Song Hong (Red River) basin in the North of Vietnam was selected for geochemical evaluation of the source rocks of its petroleum system. This basin is the second largest sedimentary basin of the country with both onshore and offshore fields. Reserves and recoverable resources in the Song Hong basin are estimated about $1.1 \mathrm{Mmscmd}$ and proven gas reserve is about $250 \mathrm{Bscm}$ (excluding $\mathrm{CO}_{2}$ ) according to PVN (2017). Geochemical evaluation of the source rocks in some parts of Song Hong basin has been done in some previous studies such as PVN (2007), Petersen et al. (2004) for some Miocene and Oligocene shale samples taken from offshore wells.

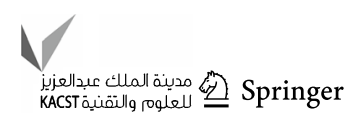


The main steps of this study include a brief review of geological setting in which these shale formations are found, followed by a description of how the samples were taken from the wells, how the geochemical tests were conducted and their results interpreted. The objective of this study is to perform a comprehensive geochemical assessment of the quality and thermal maturity of organic matter based on analysis of such properties as total organic carbon (TOC), $\mathrm{S} 2$ pyrolysis yields, hydrogen index (HI), $T_{\max }$ values and vitrinite reflectance (Ro). The study focused on three source rock formations in the petroleum system in the northern Song Hong basin, namely Lower Miocene, Oligocene and Triassic shales. The results from this study could be useful in future to calculate hydrocarbon potentially retained in shale for assessment of shale gas potential of a source rock in a sedimentary basin following an approach conducted by Sheikh and Giao (2017).

\section{Geological framework}

\section{Structural and tectonic setting of the study area}

The Song Hong basin is located between $105^{\circ} 30^{\prime}-110^{\circ} 30^{\prime} \mathrm{E}$ longitudes and $14^{\circ} 30^{\prime}-21^{\circ} 00^{\prime} \mathrm{N}$ latitudes (Fig. 1). It is an elongated basin trending NW-SE direction, about $650 \mathrm{~km}$

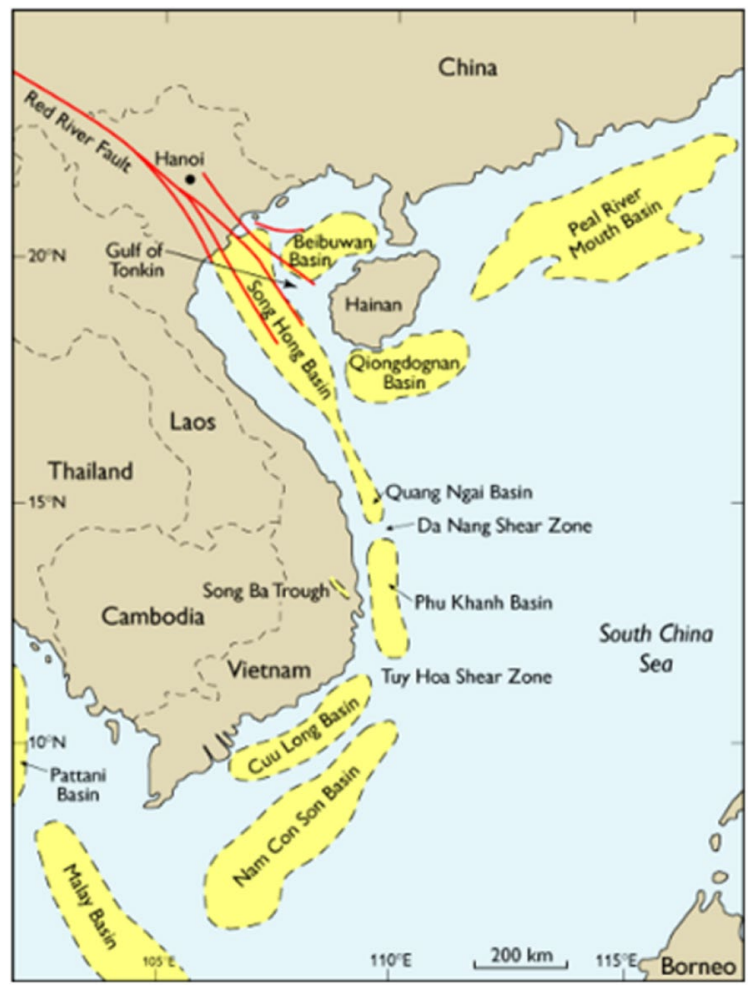

Fig. 1 Location map of Song Hong basin (PVN 2007) in length, $150 \mathrm{~km}$ in width and has more than $10 \mathrm{~km}$ of sediment thickness at its depocenter. The continuity of Song Hong basin in China's territory is known as the Yinggehai basin. The basin is surrounded by other basins such as the Beibuwan basin to the northeast, Qiongdongnan and Hoang Sa basins to the southeast. The onshore part of the Song Hong basin is known as Hanoi trough.

The study area in this research is delimited to the northern Song Hong basin as shown in Fig. 2.

Structurally, the Song Hong basin has a valley shape bounded by two main northwest to southeast trending faults, known as the Song Hong fault zone. The two main faults, which controlled the Tertiary sedimentation and deformation of the Song Hong basin, are known as Song Chay and Song Lo faults (see Fig. 2).

The formation and development of the Song Hong basin is related to large-scale extrusion and clockwise rotation of the Indochina block caused by collision of Indian and Eurasian plates. The plate started with slow rifting during early Eocene with NW-SE regional extension that caused

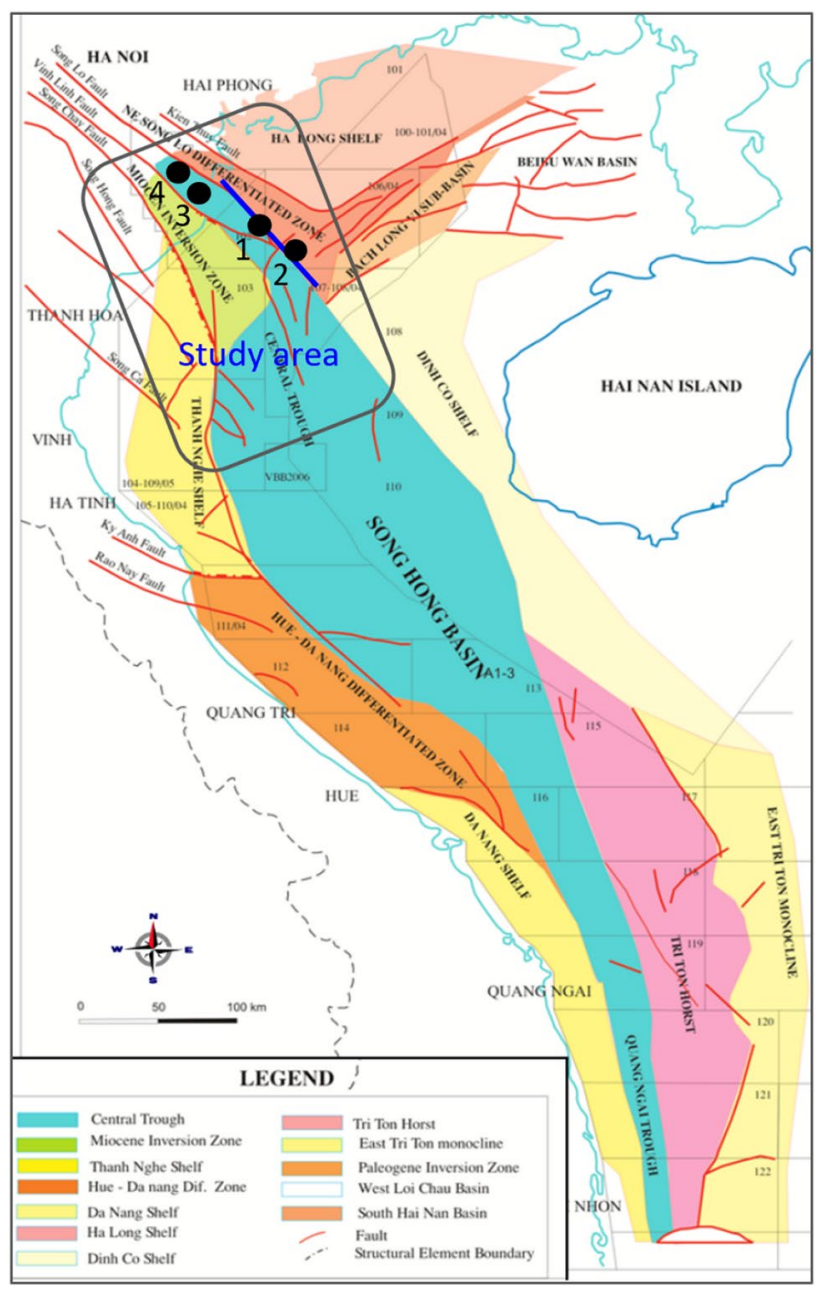

Fig. 2 The study area in the northern Song Hong basin (PVN 2007) 
the formation of NE-SW trending proto-East Sea of Vietnam (Nielsen et al. 1998). The continuing collision of Indian Plate with the Eurasian Plate during late Eocene to early Oligocene (40 Ma) has caused tectonic escape of Indochina block toward the southeast. The left lateral shear-rifting stage formed by sinistral slip of the Indochina block was followed by rapid clockwise rotation $\left(15^{\circ}-20^{\circ}\right)$. Thus, one can say the left lateral movement of about 200 to $800 \mathrm{~km}$ along the Song Hong fault system initiated the formation of Song Hong basin. The strike slip movements occurred mainly along Song Lo and Song Chay faults. During the rifting phase, grabens and half-grabens were formed in Song Hong basin, which later were filled up by fluvial and lacustrine deposits. The volume of water increased when subsidence was to be continued, the lacustrine setting open-out into marginal marine or shallow marine environment to provide more accommodation space for sedimentation. However, in the late Oligocene, the spreading out of the South China Sea to the southeast has caused compression, resulting in the inversion and uplifting of hosts and grabens in the Song Hong basin. The inversion has created a pop-up structure on overlying younger sediments followed by active erosions during late-early Oligocene that cut significant amount of earlier deposited Oligocene sections. The angular unconformity as a result of the erosions in the late Oligocene is believed to be a major breakup unconformity that separates the syn-rift and post-rift sections.

Continuous left lateral transtension along Song Hong fault systems combined with thermal cooling after the rifting stage caused further depression to this basin. The rapid subsidence has resulted to transgression and backstepping sedimentation during early Miocene. However, the southeastward drifting of the Indochina was blocked by Sundaland plate (Lee and Lawver 1994, 1995; Hall 1996) in the Middle Miocene. As the result, the relative movements along Song Hong faults changed from left lateral to right lateral. The strike slip activity, which caused the reversal of faults and the formation of significant inversion structures, partly contributed to the trapping mechanism of petroleum system in the Song Hong basin.

The geodynamic and tectonic evolution in the area has provided the structural framework for hydrocarbon trapping mechanism in the Song Hong basin that can be summarized as follows: (1) In Eocene-Oligocene, block faulting creates horst and graben structures during the rifting phase; (2) in late Oligocene, northwest-southeast opening of South China Sea caused compression (tectonic inversion) to some part of the Song Hong basin; (3) in Middle Miocene, the change of displacement direction caused formation of distinct unconformity, which in places shows deep channel incision and possible deposition of basin floor fans; and (4) in late Miocene, there was a reversal of movement on the Song Hong fault, from left lateral to right lateral, and causes inversion to older fault.

\section{Stratigraphy}

Eight major bounding surfaces have been identified based on seismic sequence stratigraphy interpretation as shown in a seismic section in Fig. 3, whose location can be found in Fig. 2. The major bounding surfaces or sequence boundaries (SB) identified in northern blocks in this study were named as top of pre-tertiary, SB1 to SB7 as shown in Fig. 3. The post-tertiary sections range from Oligocene to Pliocene. A generalized tectono-stratigraphic framework is shown in Fig. 4. Out of the eight identified regional unconformities or sequence boundaries, the top pre-tertiary unconformity experienced the longest hiatus or non-depositional period (Othman and Jaafar 2006a, b).

In general, the depositional pattern of the basin can be divided into three mega sequences. The first mega sequence from Oligocene to Lower Miocene suggests retrogradational pattern or transgressive period (rise of sea level) as a result of rapid subsidence from continuous transtensional rifting, which later followed by subsidence from thermal cooling after the rifting.

The second mega sequence from Lower to Middle Miocene shows progradational pattern resulted from series of sea-level drops during Middle Miocene as indicated by extensive incision and deposition of basin floor fans on SB3 and SB4. The third mega sequence from Upper Miocene to Recent suggests slight progradational to aggradational pattern; this pattern is normally produced when sediment supply managed to keep up with the rise of sea level or the sediment supply is in balance with the accommodation space produced by rising sea level (Othman and Jaafar 2006a, b).

\section{Materials and methods}

In this study, more than 200 ditch cuttings were taken at 20-m spacing from two pairs of offshore wells, PS-1X (488.80-2489.20 m), NRH-1X (1950.20-4093.65 m) and onshore wells, RC-1X (1484.10-1842.40 m), VD-1X (1086.40-1631.70 m), which are denoted in this study as wells 1, 2, 3 and 4 (see Fig. 2). The samples were taken from Lower Miocene, Oligocene and Triassic shale formations.

All of shale or mud samples were washed and dried to remove drilling mud (without OBM) and carefully prepared for Rock-Eval pyrolysis and vitrinite reflectivity tests at the geochemical laboratory of Vietnam Petroleum Institute (VPI). The former analysis was conducted using the RockEval 6 instrument of Vinci Technologies. The number of samples from each study shale formation for analysis of total

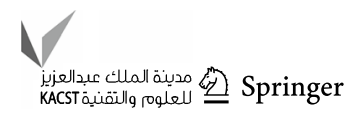



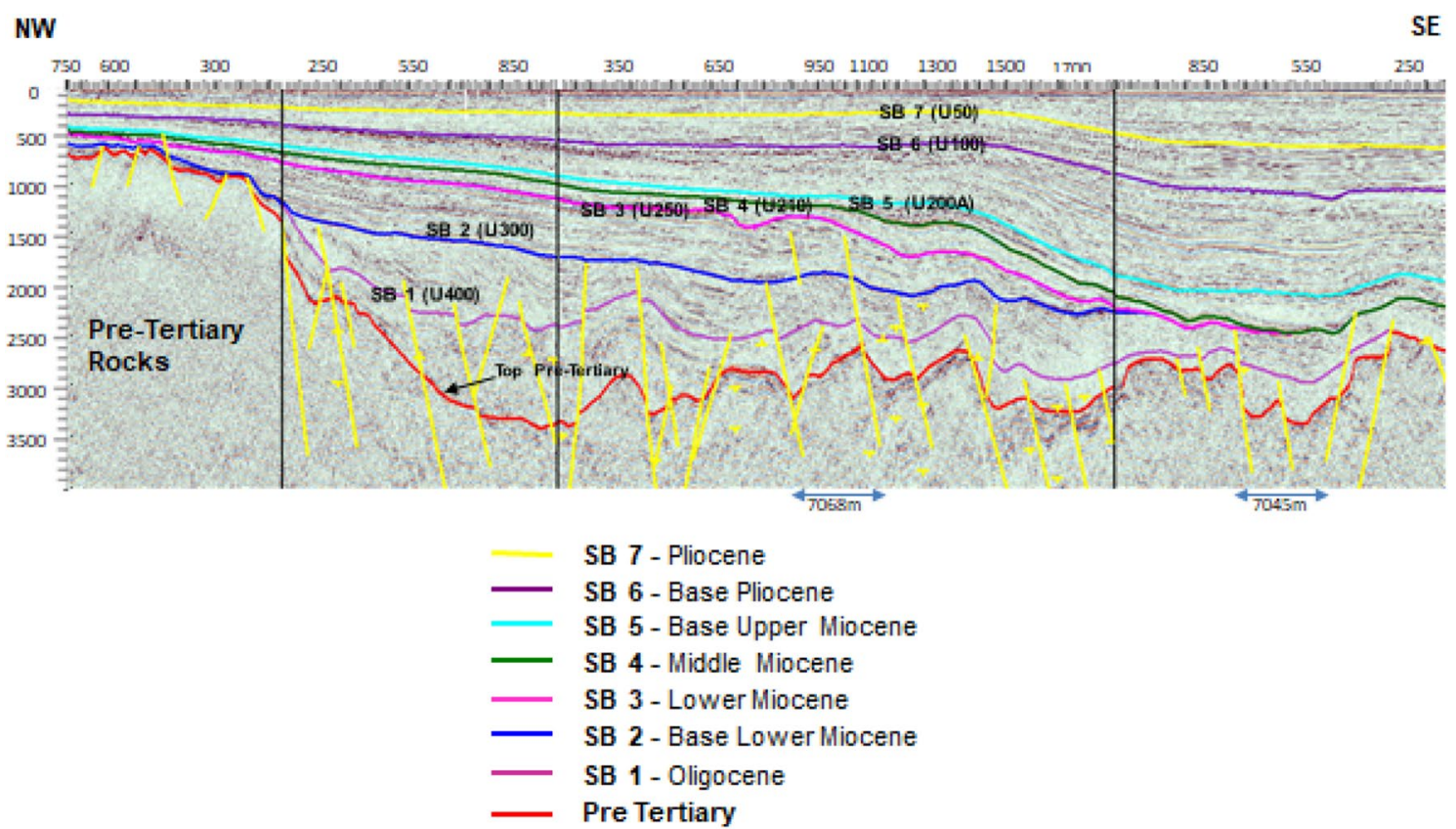

Fig. 3 Major sequence boundaries in northern blocks of Song Hong basin (Othman and Jaafar 2006a, b). Three vertical bars show the joining locations of different seismic subsections

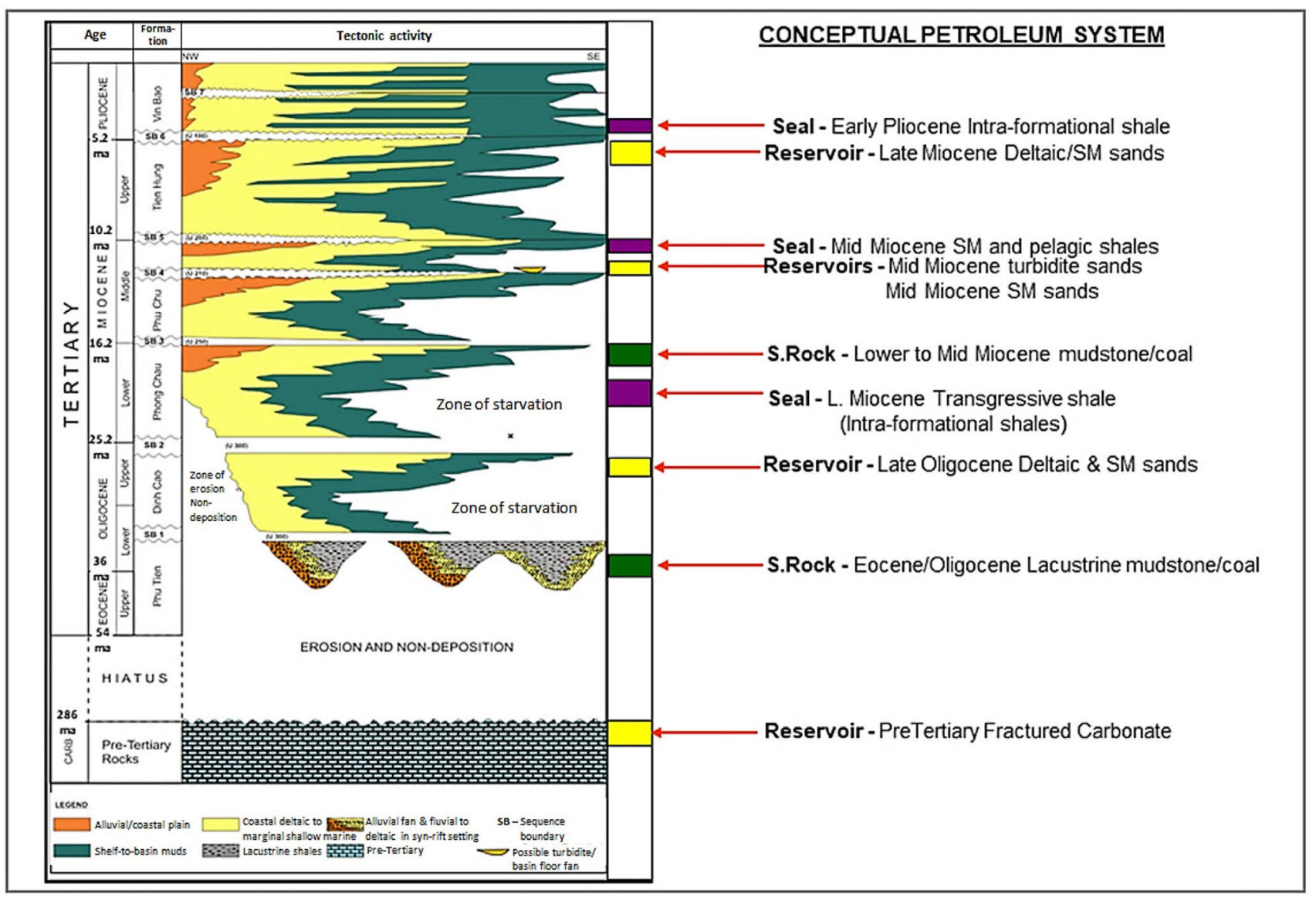

Fig. 4 Regional tectono-stratigraphic framework of the northern Song Hong basin (Othman and Jaafar 2006a, b) 
Table 1 Summary of the tested samples and geochemical analyses

\begin{tabular}{llr}
\hline Shale formation & $\begin{array}{l}\text { Quantity of } \\
\text { geochemical } \\
\text { analyses }\end{array}$ \\
\cline { 2 - 3 } & $\begin{array}{l}\text { TOC by } \\
\text { Rock- }\end{array}$ \\
& $\begin{array}{l}\text { Eval pyrol- } \\
\text { ysis }\end{array}$ \\
\hline Lower Miocene & 132 & 48 \\
Oligocene & 84 & 29 \\
Triassic & 18 & 7 \\
\hline
\end{tabular}

organic content (TOC) and vitrinite reflectance $\left(R_{0}\right)$ analyses is shown in Table 1.

\section{Rock-Eval pyrolysis}

Rock-Eval pyrolysis is used extensively for characterizing the quality, quantity and thermal maturity of organic matter in sedimentary rocks that are essential for assessing the petroleum generation potential of a sedimentary basin.

Before loading samples in crucible, all selected shale/ mud samples eliminated excess water, were checked for the absence of contaminants (drilling mud, salts, oil based mud, etc.) and were crushed in $1 \mathrm{~mm}$ to $4 \mathrm{~mm}$ size fraction.

Basically, $70 \mathrm{mg}$ of standard sample $(55,000)$ is used for loading in a conditioned crucible and run three analyses under analysis mode to check the quality of calibration. A total of 2-10 mg sample was used for each crucible and run under analysis mode. Samples are then heated in stages, initially kept isothermally at $300{ }^{\circ} \mathrm{C}$ for several minutes, followed by a programmed heating at a rate of $25{ }^{\circ} \mathrm{C}$ per minute. Released hydrocarbons are monitored by a flame ionization detector (FID), forming a peak S1 that evolved from the sample without cracking kerogen during the first stage of heating at $300{ }^{\circ} \mathrm{C}$ (Kevin et al. 2011). Following this isothermal heating step, samples were heated linearly from $300{ }^{\circ} \mathrm{C}$ to $650{ }^{\circ} \mathrm{C}$ at $25^{\circ} \mathrm{C} / \mathrm{min}$, yielding a peak S2 that corresponds to quantity of hydrocarbons resulted from the cracking of organic matter. S2 represents milligrams of residual hydrocarbons in $1 \mathrm{~g}$ of rock, indicating the potential amount of hydrocarbons the source rock might still produce if reaching to thermal maturation. The temperature at peak $\mathrm{S} 2$ can be converted to the thermal maturity parameter, $T_{\max }\left({ }^{\circ} \mathrm{C}\right)$. The $\mathrm{S} 3$ curve corresponds to the amount of $\mathrm{CO}_{2}$ ( $\mathrm{mg} \mathrm{CO} / \mathrm{g}$ of initial rock), which is monitored by infrared (IR) cells, generated from organic matter during the initial isothermal heating step and the programmed heating phase up to $400{ }^{\circ} \mathrm{C}$. $\mathrm{CO}_{2}$ generated between 400 and $650{ }^{\circ} \mathrm{C}$ is from the thermal decomposition of carbonate minerals. Pyrolysis mineral carbon is determined from the high-temperature portions of the $\mathrm{CO}$ and $\mathrm{CO}_{2}$ pyrolysis curves. The total organic carbon (wt\%) is the sum of the pyrolysable organic carbon (see Fig. 3).

\section{Vitrinite reflectance}

Vitrinite reflectance, $R_{\mathrm{o}}(\%)$, has been developed by petrologists over 60 years, and it is nowadays a reliable analytical method for determining the thermal maturation of argillaceous and calcareous rocks. It includes telinite, the cell wall material of land plants, and collinite, the substance that fills the cell cavities. $R_{\mathrm{o}}(\%)$ is the percentage of incident light reflected from a polished surface of vitrinite, which is a measure of the thermal maturity of a sedimentary rock containing kerogen. In other words, $R_{\mathrm{o}}(\%)$ is an indicator of whether a source rock has been heated enough to produce oil, oil and gas or gas only (see Fig. 5).

Kerogen isolated from shales is embedded in epoxy in epoxy plug and polished to a flat, shiny surface (Bostick and Alpern 1977; Bostick 1979). These resin blocks were ground and polished in standard because poor polishing will lead to spurious reflection measurements. The kerogen in blocks obviously contained particles of vitrinite plus other macerals (i.e., liptinites and inertinites); however, only vitrinite particles were chosen and measured under oil immersion. The number of readings depends on the abundance of vitrinite particles in the sample, but it should be in the range of 30-100 vitrinite particles.

Most source rock maturity involves $R_{\mathrm{o}}(\%)$ ranging from 0.2 to $2 \%$. The lowest value associated with generation of oil is $0.45 \%$. Oil generation peaks at a maturation level around 0.8 to $1 \%$. No major oil accumulations are associated with $R_{\mathrm{o}}$ (\%) above $1.35 \%$. The large gas/condensate fields are found with $R_{\mathrm{o}}(\%)$ ranging from 1.35 to $3 \%$. The end of condensate generation is at $R_{\mathrm{o}}(\%)$ of around $2 \%$, and the end of methane

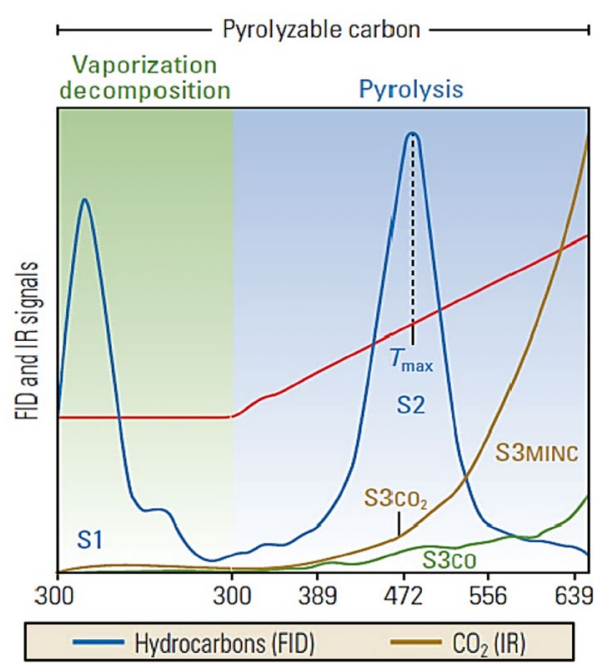

Fig. 5 Programmed pyrolysis results (Kevin et al. 2011)

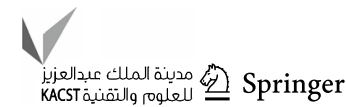



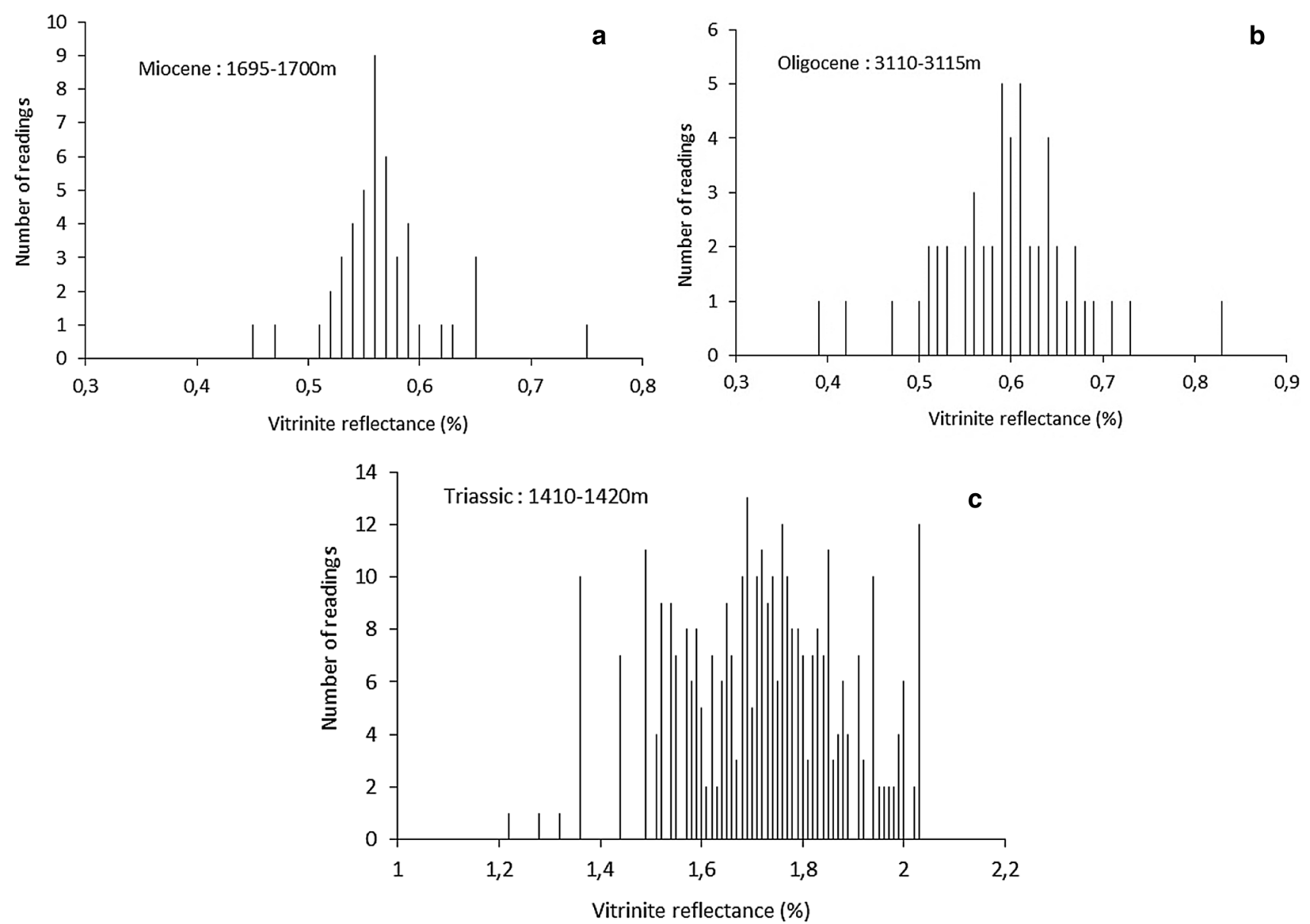

Fig. 6 Examples of vitrinite reflectance measurements of the northern Song Hong shale samples: a Miocene shale at $1695-1700$ m; b Oligocene shale at 3110-3115 m; and c Triassic shale at 1410-1420 m

generation is at $R_{\mathrm{o}}(\%)$ of around $3.5 \%$ (Dow 1977). Some examples of vitrinite reflectance measurements for Song Hong shale samples are shown in Fig. 6.

\section{Results and discussion}

For source rock assessment, the key indicators include the amount of organic matter, the hydrogen content and the level of maturation. Organic matter derived from marine sediments can include plankton, marine algae, bacteria and lipidrich components of higher plants (spores, waxes, etc.). These materials are hydrogen-rich (H/C from 1.4 to 1.6, hydrogen index higher than 700) and are oil-prone. Organic matter derived from plant material is hydrogen-poor $(\mathrm{H} / \mathrm{C}$ from 1.3 to 1.5) and is more gas-prone.

To ensure quality of data interpretation, unreliable $T_{\max }$ or $\mathrm{HI}$ values derived from very low TOC and S2 (i.e., approximately $<0.2 \mathrm{mg} \mathrm{HC} / \mathrm{g}$ rock) have been removed from the data set. The criteria by Peters and Cassa (1994) in Table 2 are used to evaluate the petroleum generation capacity of the type II kerogen-dominated shales in our study.

Assessment of the thermal maturity was mainly based on vitrinite reflectance measurement. $T_{\max }$ is also used as maturity parameter together with vitrinite reflectance. However, $T_{\max }$ is influenced by kerogen type and the mineral matrix; single $T_{\max }$ values may therefore be less reliable (Peters 1986). Identification of the primary vitrinite (i.e., indigenous or autochthonous) is essential for obtaining reliable vitrinite values as this vitrinite reflects the actual thermal maturity of the organic matter at the sampled depth. Higher reflecting vitrinite particles may represent recycled organic matter that attained higher maturity from the temperature history of its former host rock (Bostick 1979; Hunt 1996; Taylor et al. 1998). In contrast, vitrinite that yields anomalously low reflectance values may be suppressed (Buiskool Toxopeus 1983; Carr 2000a, b).

Besides, TOC values and other pyrolysis parameters are also affected by the maturity of the source rock. They will decrease, and the composition of the pyrolysate yields will be changed in progress of hydrocarbon generation. 
Table 2 Guideline for source rock interpretation (Peters and Cassa 1994)

\begin{tabular}{|c|c|c|c|}
\hline Quantity & TOC (wt\%) & $\mathrm{S} 1$ (mg HC/g rock) & $\begin{array}{l}\mathrm{S} 2(\mathrm{mg} \mathrm{HC} / \mathrm{g} \\
\text { rock) }\end{array}$ \\
\hline Poor & $<0.5$ & $<0.5$ & $<2.5$ \\
\hline Fair & $0.5-1.0$ & $0.5-1$ & $2.5-5$ \\
\hline Good & $1-2$ & $1-2$ & $5-10$ \\
\hline Very good & $2-4$ & $2-4$ & $10-20$ \\
\hline Excellent & $>4$ & $>4$ & $>20$ \\
\hline Quality & $\mathrm{HI}(\mathrm{mg} \mathrm{HC} / \mathrm{g}$ TOC) & $\mathrm{S} 2 / \mathrm{S} 3$ & Kerogen type \\
\hline Non & $<50$ & $<1$ & IV \\
\hline Gas & $50-200$ & $1-5$ & III \\
\hline Gas and oil & $200-300$ & $5-10$ & II/III \\
\hline Oil & $300-600$ & $10-15$ & II \\
\hline Oil & $>600$ & $>15$ & $\mathrm{I}$ \\
\hline Maturation & $R_{\mathrm{o}}(\%)$ & $T_{\max }\left({ }^{\circ} \mathrm{C}\right)$ & $\mathrm{PI}=\mathrm{S} 1 /(\mathrm{S} 1+\mathrm{S} 2)$ \\
\hline Immature & $0.20-0.60$ & $<435$ & $<0.10$ \\
\hline \multicolumn{4}{|l|}{ Mature } \\
\hline Early mature & $0.60-0.65$ & $434-445$ & $0.10-0.15$ \\
\hline Peak mature & $0.65-0.90$ & $445-450$ & $0.25-0.40$ \\
\hline Late mature & $0.90-1.35$ & $450-470$ & $>0.40$ \\
\hline Post-mature & $>1.35$ & $>470$ & - \\
\hline
\end{tabular}

Table 3 Results of Rock-Eval parameters and vitrinite reflectance analysis

\begin{tabular}{lllllllll}
\hline Age & TOC $(\mathrm{wt} \%)$ & $\mathrm{S} 1(\mathrm{mgHC} / \mathrm{g}$ rock) & $\mathrm{S} 2(\mathrm{mgHC} / \mathrm{g}$ rock $)$ & $\begin{array}{l}\mathrm{S} 1+\mathrm{S} 2 \\
(\mathrm{mgHC} / \mathrm{g} \\
\text { rock })\end{array}$ & $\mathrm{HI}(\mathrm{mgHC} / \mathrm{g}$ TOC) & PI & $T_{\max }\left({ }^{\circ} \mathrm{C}\right)$ & $V R_{\mathrm{o}}(\%)$ \\
\hline Lower Miocene & $0.14-1.65$ & $0.07-1.50$ & $0.34-4.62$ & $0.47-5.87$ & $94-591$ & $0.06-0.26$ & $425-437$ & $0.35-0.66$ \\
Oligocene & $0.27-3.18$ & $0.07-2.19$ & $0.63-5.61$ & $0.70-7.12$ & $164-602$ & $0.12-0.37$ & $427-476$ & $0.55-0.79$ \\
Triassic & $0.64-14.10$ & $0.01-0.24$ & $0.03-1.11$ & $0.06-1.35$ & $3-11$ & $0.07-0.42$ & $425-608$ & $1.79-2.10$ \\
\hline
\end{tabular}

Table 4 Summary of shale evaluation

\begin{tabular}{lllll}
\hline Age & HC generation potential & Kerogen type & Maturity & Products \\
\hline Lower Miocene & Poor-to-fair potential & III and II & Immature to mature & Small amount of gas \\
Oligocene & Fair to good & II and minor III & Mature to peak HC generation & Gas and oil \\
Triassic & Poor & - & Late to post-mature & Little source of HC \\
\hline
\end{tabular}

The geochemical analysis results are summarized in Tables 3, 4 and Figs. 7, 8, 9, 10, 11a-c. Depths of 219 shale samples are from 488.80 to $2390.85 \mathrm{~m}$ in Lower Miocene: from 1367.70 to $4093.65 \mathrm{~m}$ in Oligocene and from 1558.20 to $1839.46 \mathrm{~m}$ in Triassic, respectively.

\section{Lower Miocene shales}

The gray and medium brown shales in this formation have low-to-moderate organic-rich with TOC ranging from 0.14 to $1.65 \mathrm{wt} \%$, averaging $0.73 \mathrm{wt} \%$ (Table 3 and Fig. 7a). Samples from 1300 to $1540 \mathrm{~m}$ show a higher TOC of $1.14-1.65 \mathrm{wt} \%$. Rock-Eval pyrolysis data reveal moderate potential yields with $\mathrm{S} 1$ values from 0.07 to $1.50 \mathrm{mg} \mathrm{HC} / \mathrm{g}$ rock, averaging $0.36 \mathrm{mg} \mathrm{HC/g}$ rock and $\mathrm{S} 2$ values range from 0.34 to $4.62 \mathrm{mg} \mathrm{HC/g}$ rock, averaging $1.65 \mathrm{mg} \mathrm{HC} / \mathrm{g}$ rock. The obtained results suggested a poor-to-fair hydrocarbon source potential. A modified Van Krevelen diagram in Fig. 8a shows two different groups of sources, i.e., (1) the first one is predominant by the higher land plant of type III 

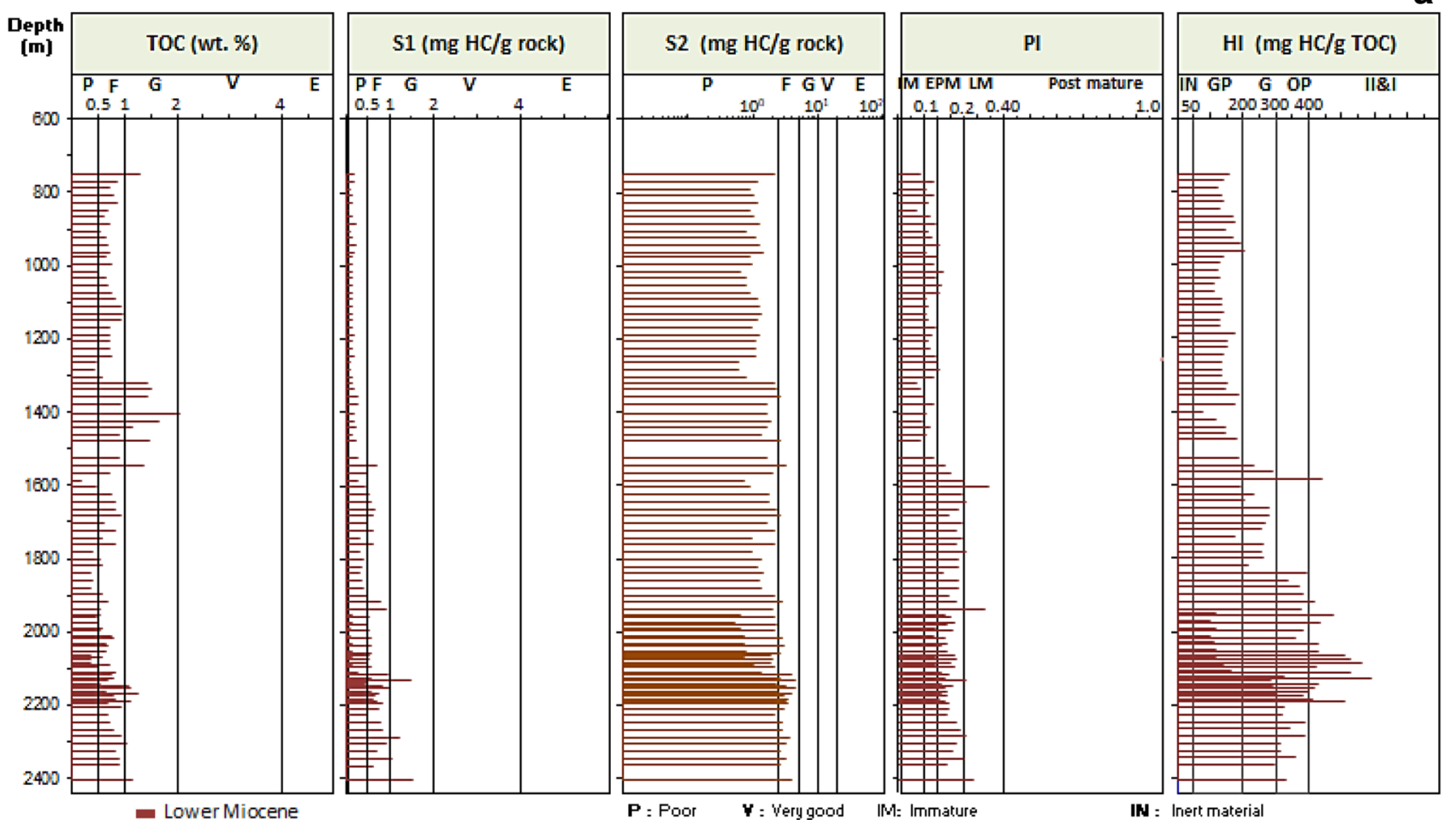

- Lower Miocene

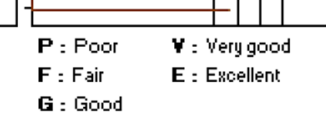

: Immature

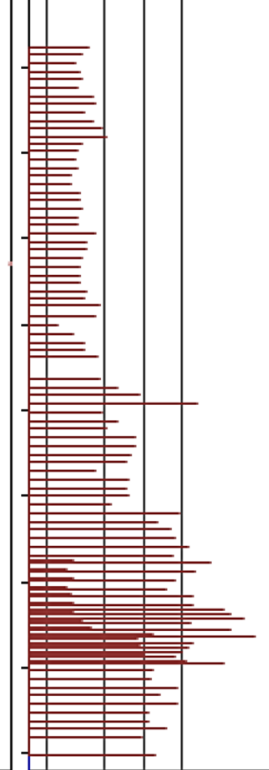

EM: Early mature

PM: Peak mature

IN : Inert material

LM: Late mature

GO : Gas \& Dil prone

OP : Gil prone of kerogen III

b

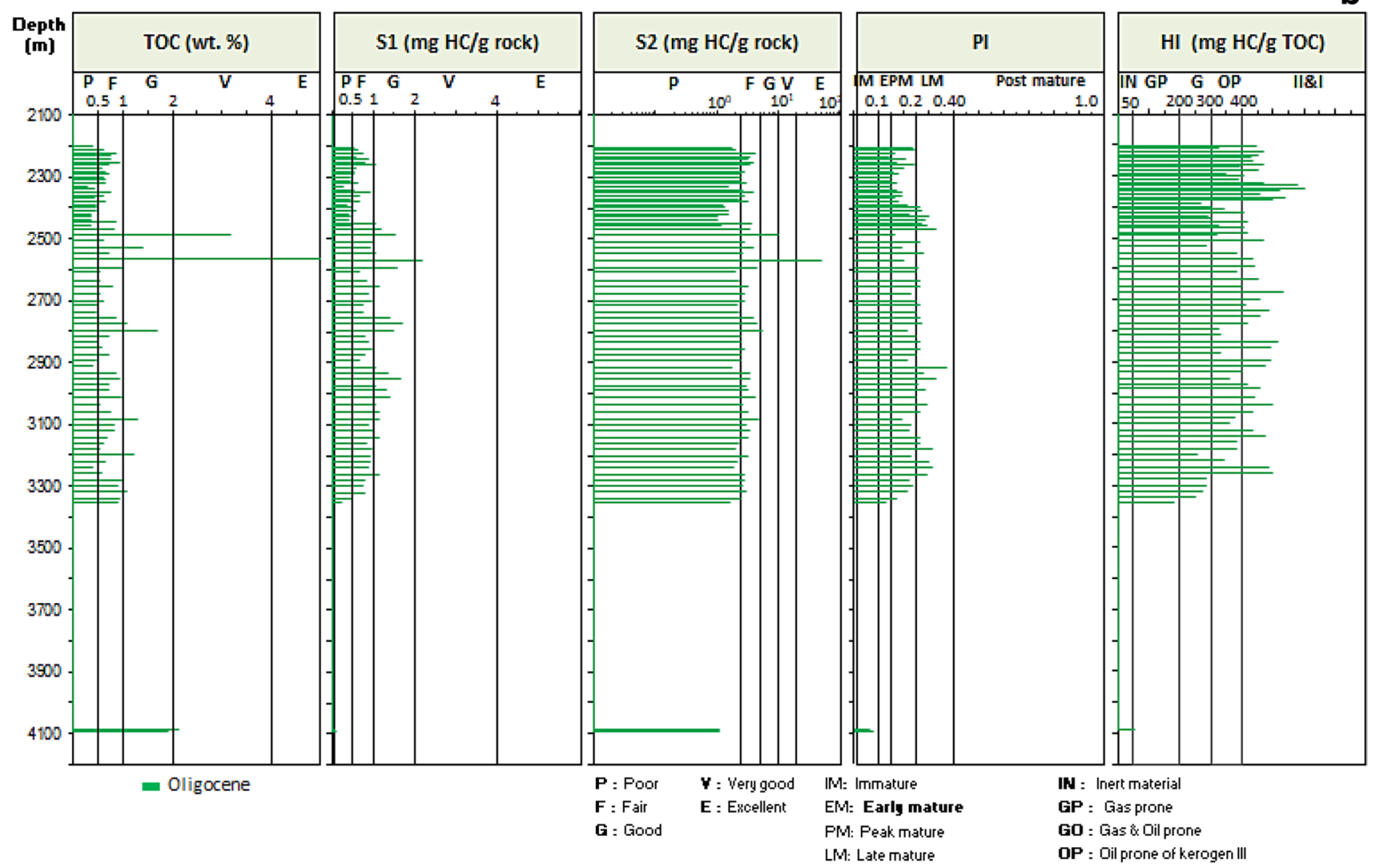

Fig. 7 a-c Change of pyrolysis parameters with depth for Lower Miocene, Oligocene and Triassic shales, respectively 


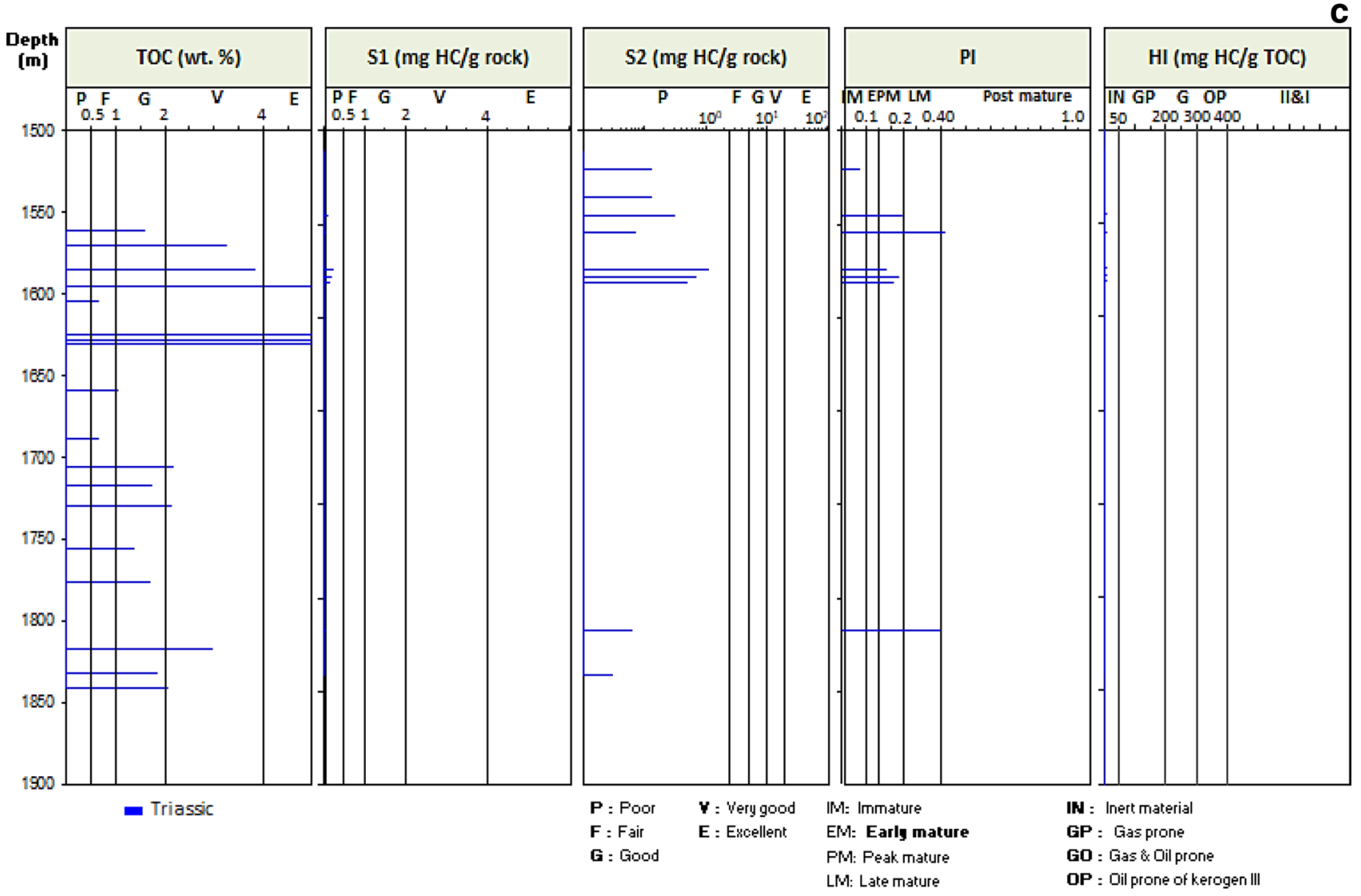

Fig. 7 (continued)

kerogen (HI: 94-277 mg HC/g TOC); and (2) the second one is predominant by algae, spore/pollen of type II kerogen (HI: 303-591 mg HC/g TOC) that are humic gas-prone and little sapropel oil-prone, respectively. On the plot of TOC versus HI (Fig. 9a), the samples of the first group fall into the zones of little source potential, while those of the second group are distributed from fair gas-prone to fair mixed and then fair oil-prone zones. There are some samples of the second group in good gas-prone zone, which come from the two offshore wells. Meanwhile, for the samples of onshore wells HI could not be calculated because there is no hydrocarbon potential (S2 nearly zero). The $T_{\max }$ values are mainly in range of 425 to $435{ }^{\circ} \mathrm{C}$, roughly corresponding to a mean vitrinite reflectivity range of 0.35 to $0.66 \%$ and PI range of 0.06 to 0.26 , all indicating that the organic matter of the Lower Miocene shale samples fell into immature stage and early-maturity stage, mainly for fair-to-good potential of gas generation (see Figs. 10a, 11a).

\section{Oligocene shales}

The Oligocene shales have fair-to-good TOC of 0.52 to $3.18 \mathrm{wt} \%$ and $\mathrm{S} 2$ yield of 0.63 to $5.61 \mathrm{mg} \mathrm{HC} / \mathrm{g}$ rock, suggesting a moderate-to-high amount of organic matter that meets the required standards of a source with fair-to-good generative potential as seen in Figs. $7 \mathrm{~b}, 8 \mathrm{~b}, 9 \mathrm{~b}$. The relationship between TOC and $(\mathrm{S} 1+\mathrm{S} 2)$ shows a fair-to-good hydrocarbon source potential as most of the samples are distributed mainly around the oil-prone line (see Fig. 10b).

Hydrogen index (HI) of most samples in this formation mainly varies from 300 to $602 \mathrm{mg} \mathrm{HC/g}$ TOC, except ten samples that have HI ranging from 50 to $291 \mathrm{mg} \mathrm{HC/g}$ TOC. Plot of HI versus $T_{\max }$ indicates that organic matter mainly originated from the type II kerogen of dominant algae, spore/pollen, etc., and little amount of higher land plant of type III kerogen (see Fig. 8b).

When a source rock matures, $\mathrm{S} 1$ increases and causes $\mathrm{S} 2$ to decrease, and thus PI is a thermal maturity indicator and increases until the onset of expulsion. All of the Oligocene samples have PI values of more than $0.1(0.12-0.37)$, $T_{\max }$ values mainly ranging from 430 to $446{ }^{\circ} \mathrm{C}$ and vitrinite reflectance mainly from 0.55 to $0.79 \%$. There is an exception of three samples with $R_{\mathrm{o}}$ values of $0.43,0.47$ and $1.73 \%$, respectively. These low Ro samples seem to contain degraded, caving and reworked vitrinite particles. In general, the geochemical parameters of Oligocene shales show that 

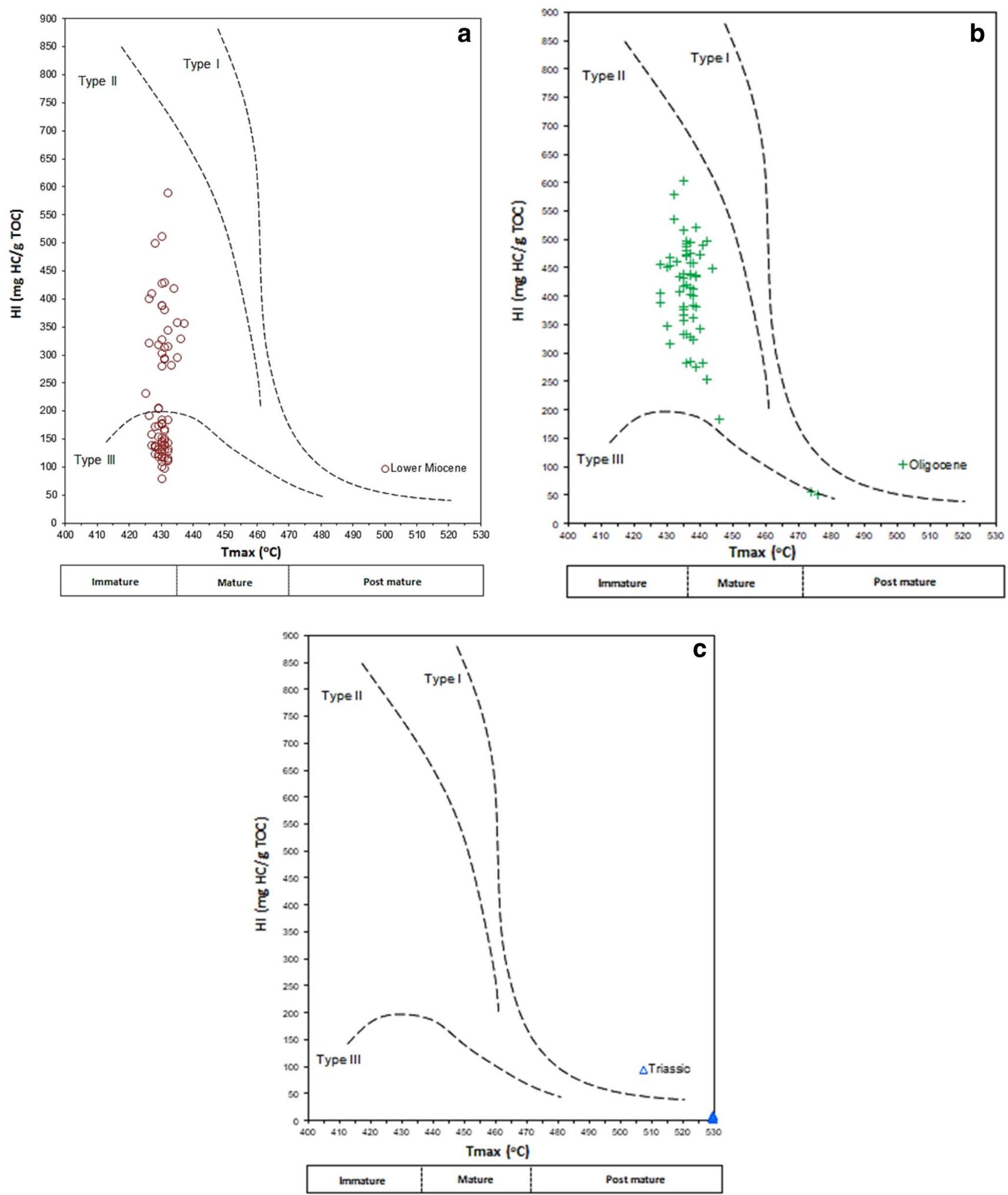

Fig. 8 a-c Organic matter type and thermal maturity for Lower Miocene, Oligocene and Triassic shales, respectively 

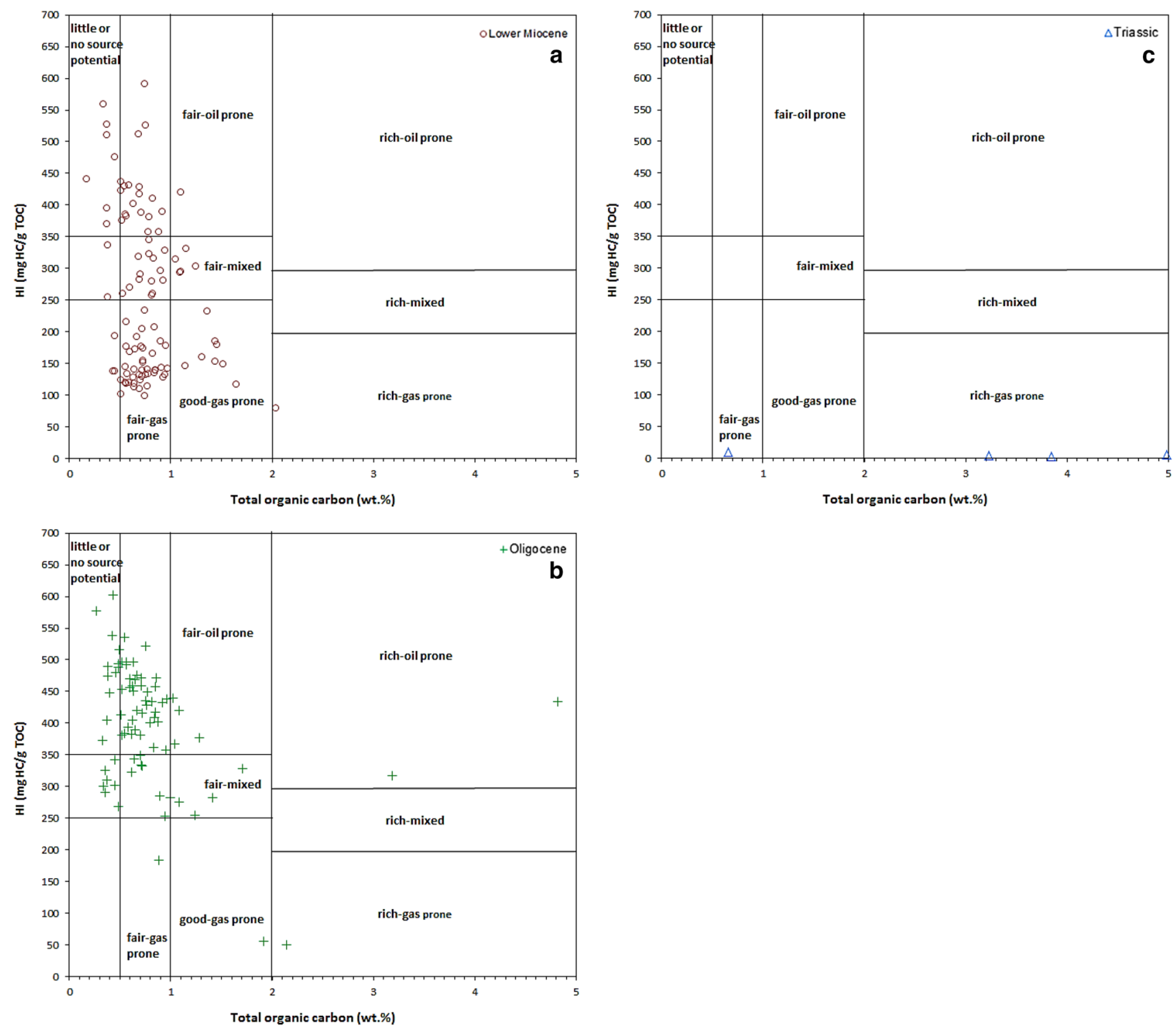

Fig. 9 a-c Hydrogen index versus total organic carbon for Lower Miocene, Oligocene and Triassic shales, respectively

they are good source rocks, their organic matter fell into mature stage and reached to peak of hydrocarbon generation (see Figs. 8b, 11b).

\section{Triassic shales}

Triassic shales are only found in onshore of the northern Song Hong basin. The TOC and pyrolysis analysis results of Triassic shales samples from two onshore wells show a wide range in TOC from $1.04 \mathrm{wt} \%$ up to $6.71 \mathrm{wt} \%$, averaging $2.92 \mathrm{wt} \%$, except one shale sample of thin section at the depth of 1621.9-1626.8 m shows very high TOC of $14.10 \mathrm{wt} \%, \mathrm{~S} 2=1.11 \mathrm{mg} \mathrm{HC} / \mathrm{g}$ rock, $\mathrm{HI}=8 \mathrm{mg} \mathrm{HC} / \mathrm{g}$ TOC,
$R_{\mathrm{o}}=1.79 \%$ (see Fig. $7 \mathrm{c}$ ). This high variation of TOC contents may result from mixed effects of the original depositional environment and progressive post-depositional diagenesis and catagenesis (thermal maturation), whereas the Rock-Eval pyrolysis data (S1 and S2) are of very poor values ranging from 0.01 to $0.24 \mathrm{mg} \mathrm{HC/g}$ rock and 0.01 to $1.11 \mathrm{mg} \mathrm{HC} / \mathrm{g}$ rock, respectively. Some samples have HI values of $<50 \mathrm{mg} \mathrm{HC} / \mathrm{g}$ TOC and $T_{\max }$ of no $>435^{\circ} \mathrm{C}$, whereas for some other samples one could not calculate $\mathrm{HI}$ and define correct $T_{\max }$ due to S1 and S2 being near at zero. High vitrinite reflectance values from 1.79 to $2.10 \%$ indicate that the organic matter had reached the late and post-thermal mature gas-bearing shales or were totally oxidized. It plots 

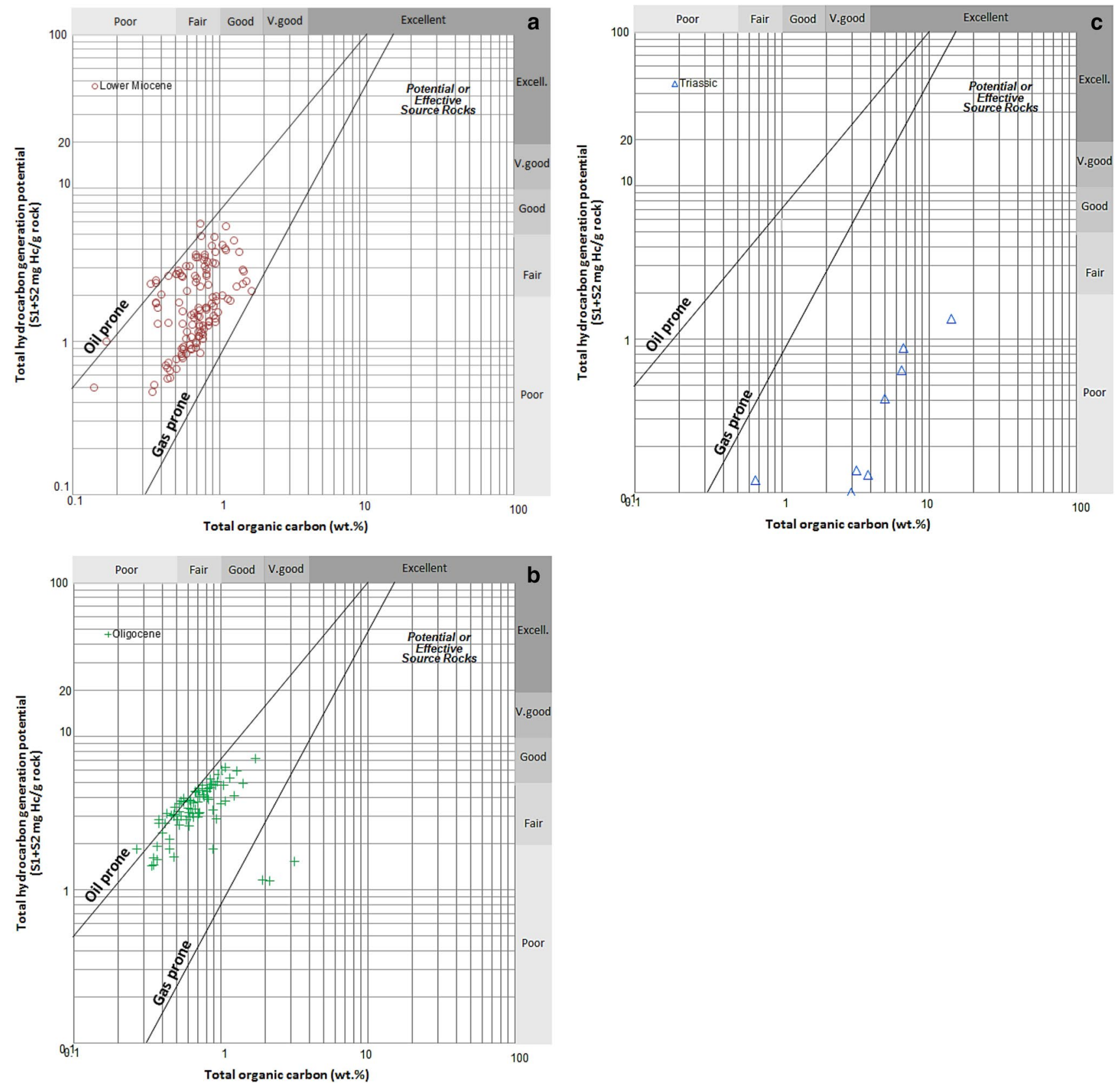

Fig. 10 a-c Total hydrocarbon generation potential versus total organic carbon for Lower Miocene, Oligocene and Triassic shales, respectively

as being a type III/IV source rocks because it has remaining capacity to generate little amount of dry gas or no potential (see Figs. 7, 8, 9, 10, 11a-c).

Lower Miocene and Oligocene shales from offshore wells have been ever discussed before; however, they were not interpreted into detail and only used as internal reports. Therefore, this study combines Lower Miocene, Oligocene and Triassic interpretation in both onshore and offshore areas to define its effective source rocks that will support information for next studies of investigating shale resources and petroleum system in the northern Song Hong basin. These results show that only Lower Miocene and Oligocene are effective source rocks in this study area based on Rock-Eval pyrolysis and vitrinite reflectance results. However, evaluation of thermal maturity for these samples is still limited because vitrinite particles are partly oxidized and degraded, giving low reliable values. It needs to do more analyses for determining thermal maturity support to kerogen type I and type II such as SCI/TAI, Raman and kinetics. Besides, it should do more detailed geochemical tests such 
as GC, GCMS for Lower Miocene and Oligocene shales for more information. In addition, more research on onshore source rocks is needed to be done for investigating shale gas in the northern Song Hong basin.

\section{Conclusions and recommendations}

Based on the results of geochemical evaluation of shale source potential by laboratory geochemical analyses such as TOC, Rock-Eval pyrolysis and vitrinite reflectance measurements of more than 200 samples taken from Tertiary and Triassic source rocks in the northern Song Hong basin, the following conclusions could be drawn, namely:

1. Thick layers of Lower Miocene shales contain predominantly type III kerogen of gas-prone and minor type II kerogen of oil-prone, the organic matter varying from poor to fair, falling into immature to thermally mature stages and capable of generating gas;

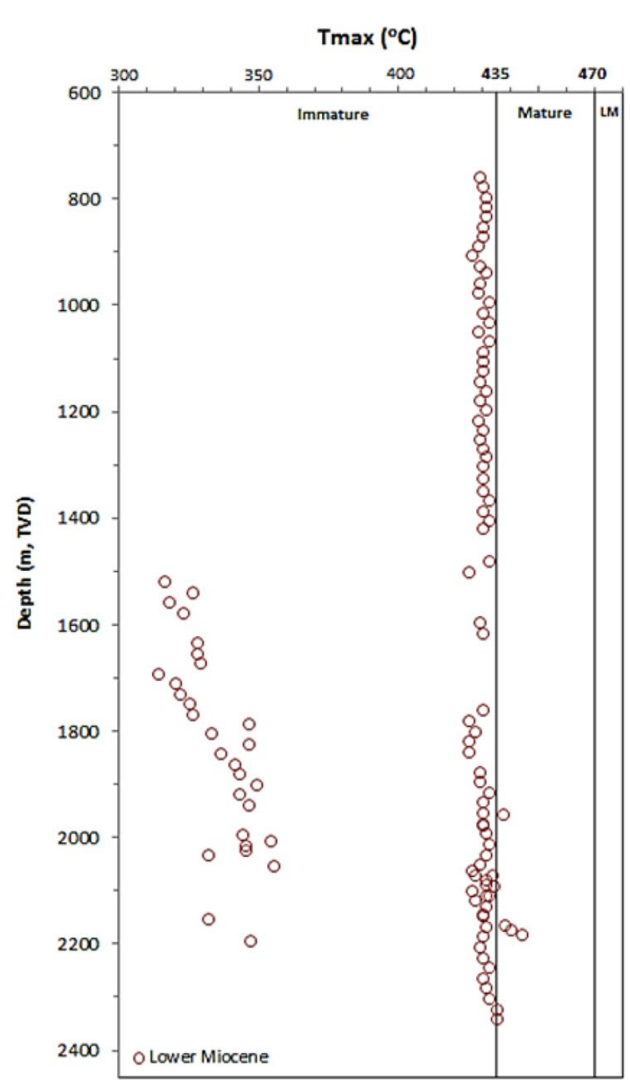

2. Oligocene shales contain mainly type II kerogen with minor type III kerogen and could sufficiently generate gas and oil from fair-to-good organic matter contents, fair-to-good hydrocarbon yields which had reached the mature stage and peak of generation. In this study, Oligocene shales comprise the main source rocks in the northern Song Hong basin;

3. Triassic source rocks show fair-to-good total organic contents, however, having poor hydrocarbon yields, giving little source for gas or no hydrocarbon generation potential in late to post-mature stages.

The screening interpretation is typically based on the Rock-Eval data; however, this might not be suitable for high maturity samples, e.g., samples in Triassic formation of this study. It is not excluded the possibility that there is a different petroleum system compared to that of Lower Miocene and Oligocene formations. Therefore, more geochemical studies need to be done in future for not only the northern Song Hong part but the whole basin.

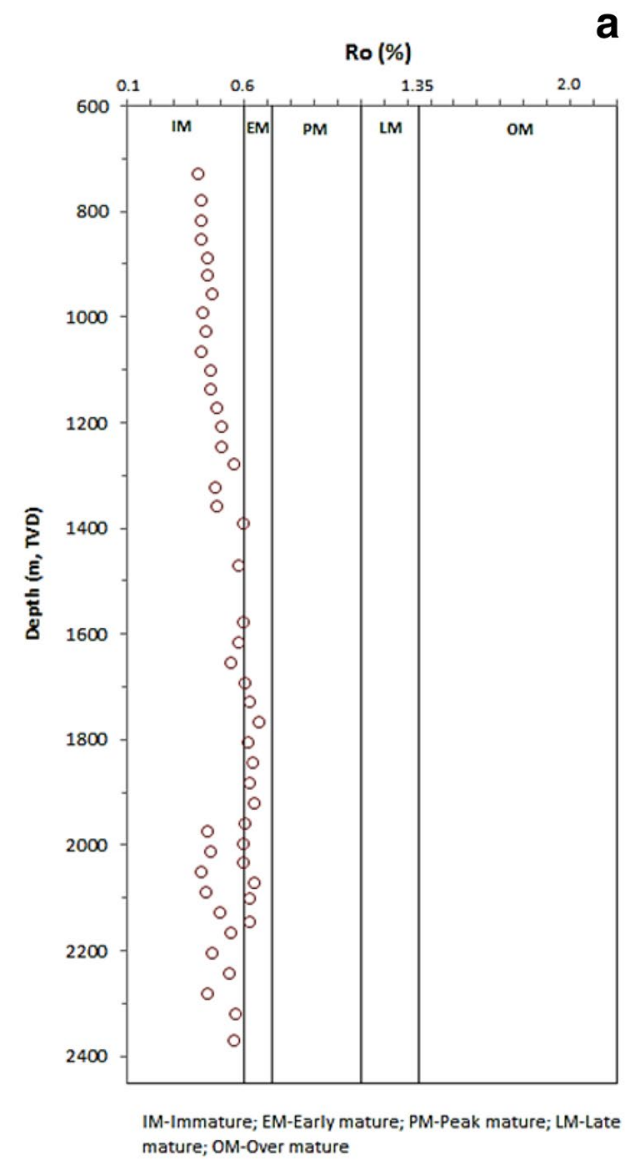

Fig. 11 a-c Change of thermal maturity of shales with depth for Lower Miocene, Oligocene and Triassic shales, respectively 

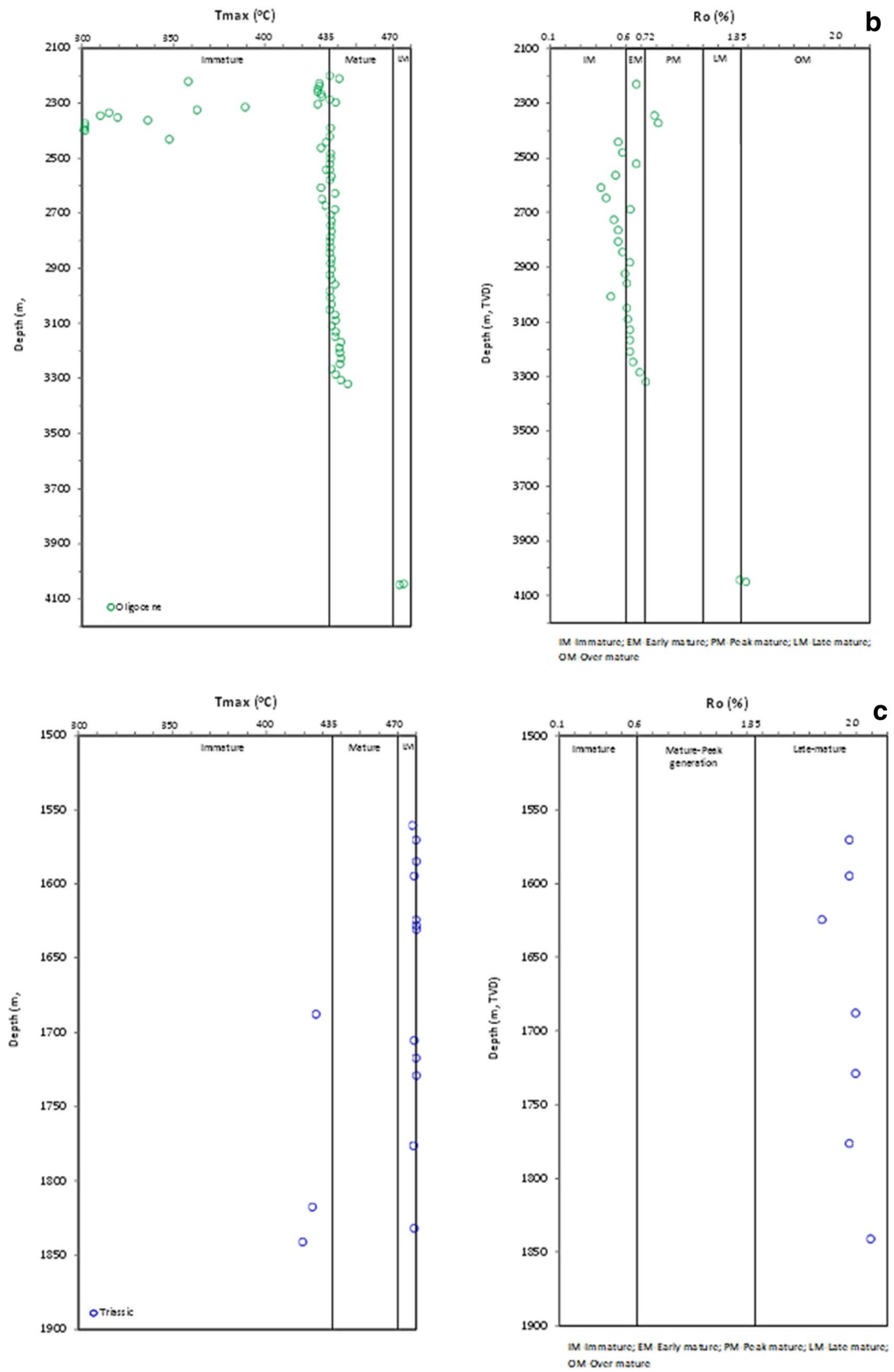

Fig. 11 (continued) 
Acknowledgements This study is supported by VPI-labs, Vietnam Petroleum Institute (VPI), PetroVietnam Exploration Production Corporation (PVEP) and Asian Institute of Technology (AIT), Thailand. Our sincere thanks are extended to the peer reviewers, whose detailed and constructive comments have helped improve the final manuscript.

Open Access This article is distributed under the terms of the Creative Commons Attribution 4.0 International License (http://creativeco mmons.org/licenses/by/4.0/), which permits unrestricted use, distribution, and reproduction in any medium, provided you give appropriate credit to the original author(s) and the source, provide a link to the Creative Commons license, and indicate if changes were made.

\section{References}

Bostick NH (1979) Microscopic measurements of the level of catagenesis of solid organic matter in sedimentary rocks to aid exploration for petroleum and to determine former burial temperatures-a review. SEPM Spec Publ 26:17-43

Bostick NH, Alpern B (1977) Principles of sampling, preparation, and constituent selection for microphotometry in measurement of maturation of sedimentary organic matter. J Microsc 109:41-47

Buiskool Toxopeus JMA (1983) Selection criteria for the use of vitrinite reflectance as a maturity tool. Petroleum geochemistry and exploration of Europe. Geol Soc Spec Publ 12:295-307

Carr AD (2000a) Suppression and retardation of vitrinite reflectance. Part 1. Formation and significance for hydrocarbon generation. $\mathrm{J}$ Pet Geol 23:313-343

Carr AD (2000b) Suppression and retardation of vitrinite reflectance. Part 2. Derivation and testing of a kinetic model for suppression. J Pet Geol 23:475-496

Dejam M, Hassanzadeh H, Chen Z (2018) Semi-analytical solution for pressure transient analysis of a hydraulically fractured vertical well in a bounded dual-porosity reservoir. J Hydrol 565:289-301

Dow WG (1977) Kerogen studies and geological interpretations. J Geochem Explor 7:79-99

EIA (2013) Technically recoverable shale oil and shale gas resources: an assessment of 137 shale formations in 41 countries outside the United States. US Energy Information Administration, Washington, pp 2-10

Hall R (1996) Reconstructing Cenozoic SE Asia. In: Hall R, Blundell DJ (eds) Tectonic evolution of Southeast Asia, vol 106. Geological Society of London Special Publication, London, pp 203-224
Hunt JM (1996) Petroleum geochemistry and geology. W.H. Freeman and Company, New York, p 743

Kevin MKJ, Martin N, Daniel P, Kenneth P (2011) Basic petroleum geochemistry for source rock evaluation. Schlumberger Oilfield Rev Summer 23(2):32-43

Lee T-Y, Lawver LA (1995) Cenozoic plate reconstruction of Southeast Asia. Tectonophysics 251:85-138

Nielsen LH, Mathiesen A, Bidstrup T, Vejbñk OV, Dien PT, Tiem PV (1998) Modelling of hydrocarbon generation in the Cenozoic Song Hong basin, Vietnam: a highly prospective basin. J Asian Earth Sci 17(1):269-294

Othman AM, Jaafar U (2006a) Sequence stratigraphic study of blocks 102 \& 106 Song Hong basin Northern Vietnam. Report on blocks 102 and 106 of Song Hong basin, Petronas, Vietnam

Othman AM, Jaafar U (2006b) Sequence stratigraphic study of blocks 102 \& 106 Song Hong basin Northern Vietnam, pp 9-17

Peters KE (1986) Guideline for evaluating petroleum source rocks using programmed pyrolysis. AAPG Bull 70(3):318-329

Peters KE, Cassa MR (1994) The petroleum system-from source to trap. Applied source rock geochemistry. AAPG Mem 60:93-120

Petersen HI, Nytof HP, Nielsen LH (2004) Characterisation of oil and potential source rocks in the northeastern Song Hong basin, Vietnam: indications of a lacustrine-coal sourced petroleum system. Org Geochem 35(2004):493-515

PVN (2007) Geology and petroleum resources of Vietnam. In: Hiep N, Dac NV (eds) Petrovietnam (PVN). Science and Technology Publisher, Hanoi, Vietnam, p 549

PVN (2017) Oil and gas exploration and production, internal report by Petrovietnam (PVN), Hanoi, Vietnam

Sheikh N, Giao PH (2017) Evaluation of shale gas potential in the Lower Cretaceous Sembar Formation, the Southern Indus Basin, Pakistan. J Nat Gas Sci Eng 44(2017):162-176

Taylor GH, Teichmüller M, Davis A, Diessel CFK, Littke R, Robert P (1998) Organic petrology. Gebrüder Borntraeger, Berlin, p 704

Zhang L, Kou Z, Wang H, Zhao Y, Dejam M, Guo J, Du J (2018) Performance analysis for a model of a multi-wing hydraulically fractured vertical well in a coalbed methane gas reservoir. J Pet Sci Eng 166:104-120

Publisher's Note Springer Nature remains neutral with regard to jurisdictional claims in published maps and institutional affiliations. 